肺切除で診断が確定し，術後経過に応じて化学療法を施行した 肺 MALT リンパ腫の 4 例

名波 勇人 ${ }^{* 1}$, 三由 僚*1, 土屋 恭子*1
森木 利昭 ${ }^{* 2}$, 前田 明則 ${ }^{* 3}$, 千原 幸司*1

\begin{tabular}{|c|}
\hline 要 \\
\hline 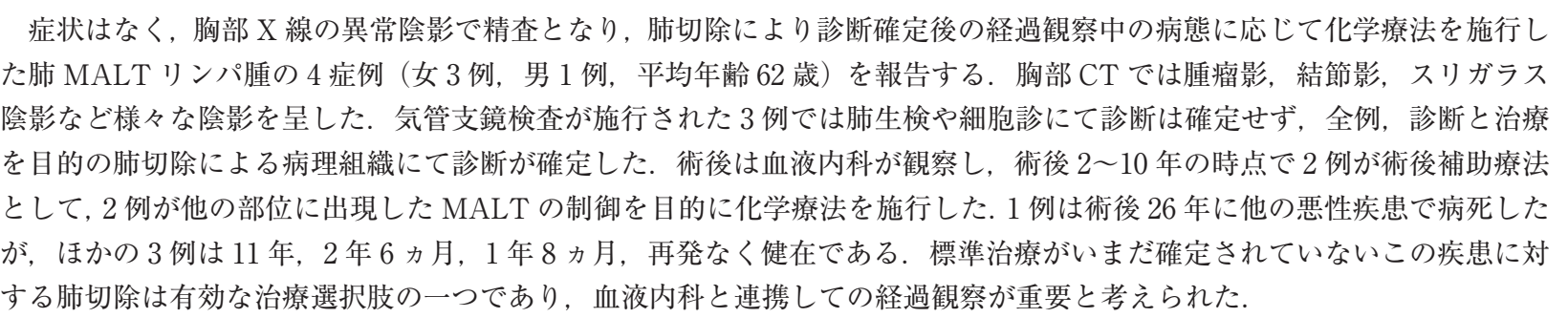 \\
\hline
\end{tabular}

索引用語 : 肺 MALT リンパ腫, 肺切除, スリガラス陰影, リンパ上皮病変, 化学療法 pulmonary mucosa-associated lymphoid tissue, lung resection, ground glass opacity (GGO), lymphoepithelial lesion (LEL), chemotherapy

\section{はじめに}

リンパ組織球系腫瘍に分類される肺 MALTリンパ腫 は肺腫瘍の約 $0.5 \%$ と稀であり, 標準治療が確立されてい ない1-3). 本疾患は, 胸部 CT 画像所見も多岐にわたり, 肺 癌などほかの疾患との鑑別が困難とされる は胸部 X写真の異常陰影を契機に精査が行われるも, 診 断が確定せず, 診断と治療を目的に肺切除を行い, 確定 診断後の経過観察中の病態に応じて化学療法を施行した 肺 MALT リンパ腫の 4 例を報告する.

\section{症例}

症例 $1: 62$ 歳, 女性.

\footnotetext{
${ }^{* 1}$ 地方独立行政法人静岡市立静岡病院呼吸器外科

*2同 病理診断科

*3同 血液内科

原稿受付 2020年 6 月 2 日

原稿採択 2020年11月26日
}

経 過：1994 年, 下血精査により小腸腫瘍が疑われ, 小腸切除が施行され病理診断は小腸 MALT リンパ腫疑 いとなった. 同時に胸部 X 線写真では腫瘤陰影も認めら れ, 小腸切除より 2 週間後, 診断治療目的に呼吸器外科 に入院となった. 血液検査では LDH 347 U/I 以外に特記 すべき異常值は認めず，全身疾患を疑う身体所見も認め なかった. 胸部単純 CT では左 $\mathrm{S}^{9+10}$ に心膜に接するよう に $63 \times 57 \mathrm{~mm}$ の楕円形の充実型の腫瘤影を認めた（Fig. 1A). 遠隔転移,リンパ節転移は認めなかった. 肺 MALT リンパ腫が疑われるも肺癌も否定はできないので, 診断 と治療を目的に手術を施行した。

手術所見：腫瘤は左 $S^{9+10}$ にあり，胸膜に包まれ $6 \times 6$ $\mathrm{cm}$ で表面平滑, 弾性硬であった. 術中穿刺迅速診断は悪 性リンパ腫疑いであったが大きな腫瘤でもあり, 切除も 治療選択肢なので左下葉切除を行った。病理組織検查の $\mathrm{HE}$ 染色では, リンパ腫細胞が気管上皮組織や腺上皮組 織を浸潤している Lymphoepithelial lesion（LEL）を認 め, 免疫染色では CD20 陽性, 染色体検査で $\mathrm{t}(11: 18)$ 


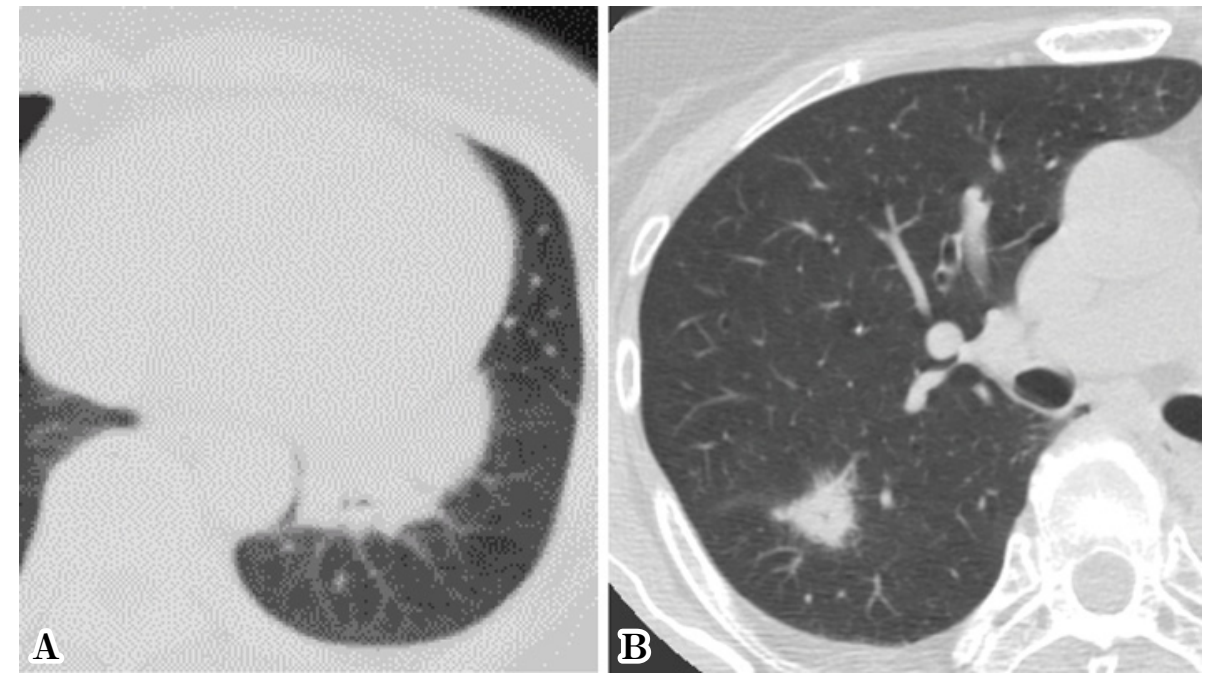

Fig. 1

A: CT showing a $63 \times 57$-mm solid mass with air-bronchogram in the left lower lobe.

B: CT showing a new $24 \times 20$-mm solid nodule in the right upper lobe.

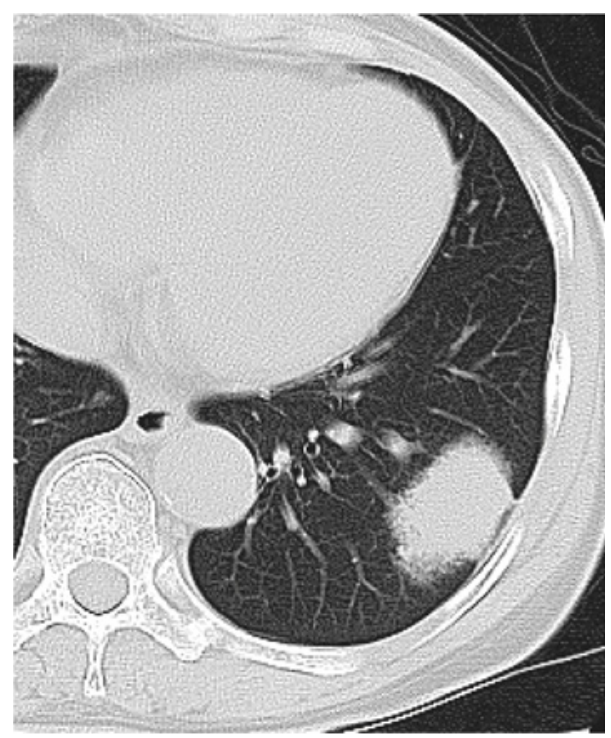

Fig. 2 CT showing a solid mass of $36 \times 27$ $\mathrm{mm}$ with peripheral GGO in the left lung $\mathrm{S}^{9}$.

の転座が見られたことから肺 MALT リンパ腫と診断し た. 小腸腫瘍も MALT リンパ腫が確定した.

術後は血液内科にて経過観察となった。再発なく良好 であったが, 術後 10 年目の胸部 CT で右 $\mathrm{S}^{6}$ の気管支血 管束に $24 \times 20 \mathrm{~mm}$ の結節 (Fig. 1B) が確認され, 1 年後 には内部に含気を含む結節陰影となった。新たな肺 MALT リンパ腫の発症と診断し, 化学療法 (R-CHOP ;
Rituximab + Cyclophosphamide + Doxorubicin + Vincristine + Prednisone）を施行した. 化学療法後はこの病変は 増大なく，新たな新規陰影も出現しなかった。 その後, 経過良好であったが, 術後 25 年に膵臓がんが出現し, 逝 去した。

症例 $2: 67$ 歳, 女性.

経 過：2008 年,健診胸部 X 線写真で腫瘤影が指摘さ れ, 胸部 CT で原発性肺癌が疑われた. 気管支鏡検查で肺 MALT リンパ腫疑いとなるも, 診断確定のため肺切除目 的で入院となった。身体所見, 血液検查に異常なし. 胸 部 CT では左 $\mathrm{S}^{9} に 36 \times 27 \mathrm{~mm}$ の周辺に気泡状の含気部 分と充実部分がモザイク状の院影を持つ充実型の腫瘤影 を認めた (Fig. 2). 手術時, 左 $\mathrm{S}^{9}$ の腫瘤周囲の臓側胸膜 は白色〜黄色に変色しており, 軽度の胸膜嵌入を認めた。 腫瘤を含めて左下葉 $S^{9}$ 部分切除を施行し, 迅速診断はリ ンパ腫疑いであった. 術後の病理組織検査により肺 MALT リンパ腫が確定した. 術後 2 カ月後, 血液内科で 補助療法として化学療法 (CP ; Cyclophosphamide+ Prednisone) 療法が施行され術後 11 年, 無再発で生存中 である。

症例 3:69 歳, 女性.

経 過：2016 年, 健診胸部 CT 結節影が発見され精查 が開始された，気管支鏡検查では診断は確定せず経過観 察となった. 6 力月後, 増大傾向が認められたため当科に 紹介された．胸部 CT では左 $\mathrm{S}^{10} に 15 \times 14 \mathrm{~mm}$ の充実型 
の結節を認め (Fig. 3), FDG-PET/CT では左下葉の結節 にSUVmax：3.1の FDG 集積光進を認めた。肺癌疑い (cT1bN0M0, cStage IA) として手術となった. 術中迅速 診断ではリンパ球の集簇を認めるものの診断確定に至ら ず胸腔鏡下左下葉切除を行った. 術後の病理組織検查に より肺 MALT リンパ腫が確定した。術後は血液内科が 化学療法を提案したが, 患者の希望に沿って経過観察と なった. しかし, 術後半年の PET-CTにてTh10, 11 の右傍脊椎, 縦隔・肺門リンパ節に FDG 集積が認めら れ，低悪性度リンパ腫の浸潤疑いとして RB（Rituximab + Bendamustine) 療法 4 コースを施行し, 右傍脊椎の病 変は消失した. 術後 2 年 6 カ月現在, MALT と考えられ

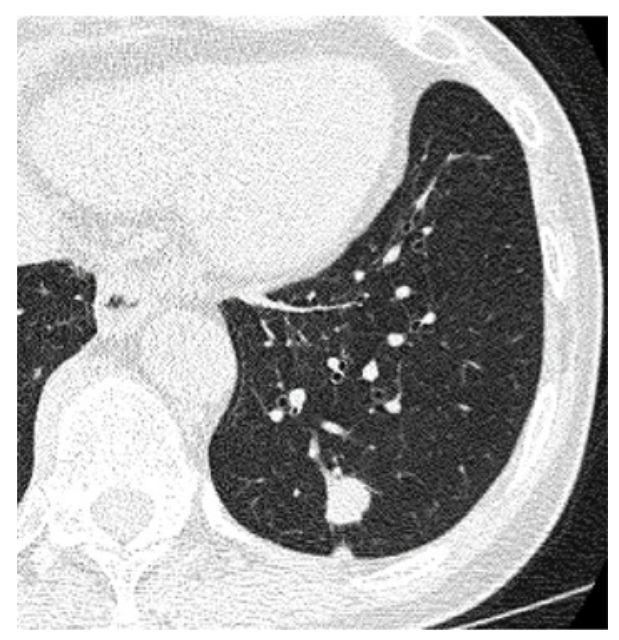

Fig. 3 CT showing a $15 \times 14$-mm solid nodule in the left lung.
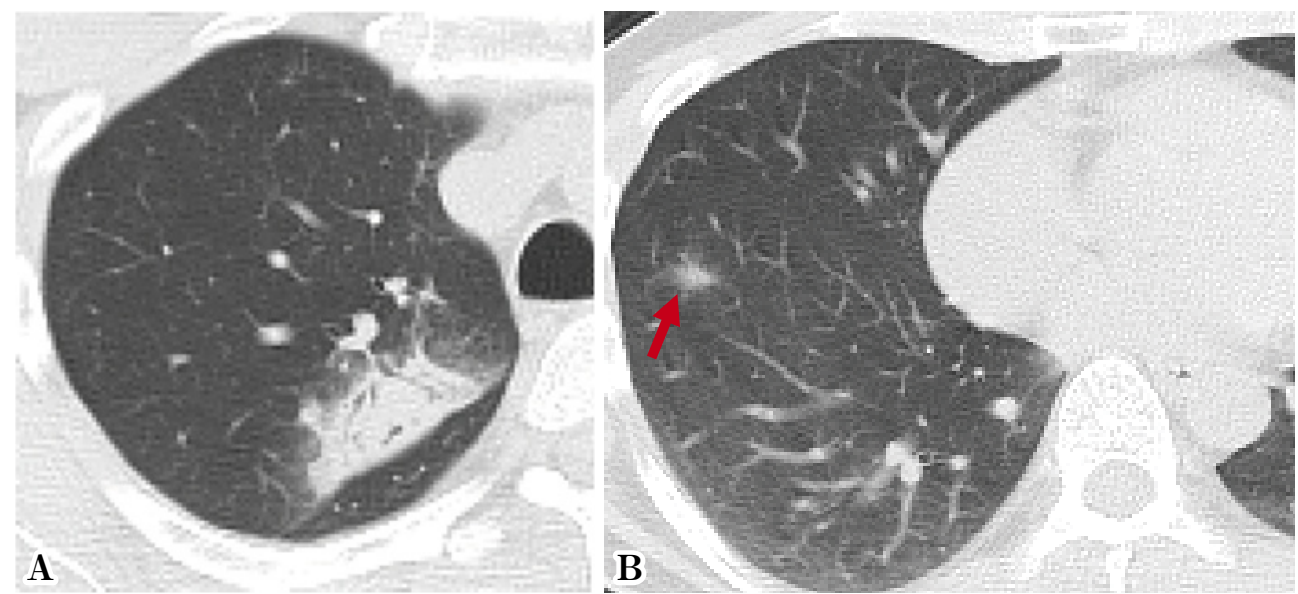

Fig. 4

A: CT showing a $40 \times 21$-mm consolidation with air-bronchogram in the right upper lobe.

B: CT showing a $12 \times 9$-mm part-solid GGO in the right lung $\mathrm{S}^{8}$.
る病変はなく，経過観察中である，

症例 $4: 48$ 歳, 男性.

経＼cjkstart過：2017 年,健診胸部 X 線写真で右肺に異常影を 指摘され, 1 年後の胸部 CT で右上葉 $\mathrm{S}^{2}$ に $40 \times 21 \mathrm{~mm}$ の内部に気管支透亮像を有する濃度の濃い浸潤影（Fig. 4A），右下葉 $\mathrm{S}^{8} に 12 \times 9 \mathrm{~mm}$ の Part Solid GGO（Fig. 4 B), 両側肺野に複数個の $2 \sim 3 \mathrm{~mm}$ の微小結節が確認さ れた. 感染症として抗菌薬治療が行われたが陰影に変化 せず，気管支鏡検査でも診断確定には至らなかった。 FDG-PET/CT では右 S $\mathrm{S}^{2}$ の腫瘤影の SUVmax は 3.62, 右 $\mathrm{S}^{8}$ の GGO はSUVmax 0.97 であった. 経過と画像所見か ら肺リンパ腫あるいは原発性肺癌の一義的な疾患あるい は両者の合併などが考えられ，治療方針選択と予後の予 測を目的の手術となった. 手術時, 右 $\mathrm{S}^{2}$ の腫瘤は透明な 灰白色の胸膜に包まれ, 胸膜嵌入は認めなかった。胸腔 鏡下右上葉切除術 + 下葉部分切除術を施行した. 術中迅 速診断はいずれも肺悪性リンパ腫疑いであり, 術後の病 理組織検査により肺 MALTリンパ腫が確定した.

血液内科が経過観察したが, 術後 1 年 6 カ月の胸腹部 CT では両側肺の微小結節に著変はなかったが, 横行結 腸に壁肥厚が確認され，消化器内科にて施行された下部 消化管内視鏡下の生検により同部位は MALT リンパ腫 が確認された。これにより Rituximab 単剤療法を 3 コー 又施行し, 術後 1 年 8 力月, 経過観察中である.

\section{考察}

肺悪性リンパ腫の約 $60 \%$ は低悪性度悪性リンパ腫に 
Table 1 Clinical features of four patients with pulmonary MALT lymphoma

\begin{tabular}{|c|c|c|c|c|}
\hline Case & 1 & 2 & 3 & 4 \\
\hline Sex & Female & Female & Female & Male \\
\hline Age & 62 & 67 & 69 & 48 \\
\hline Trigger of Diagnosis & $\begin{array}{l}\text { CxR during } \\
\text { examination for small } \\
\text { intestine disease }\end{array}$ & $\begin{array}{l}\text { CxR at medical } \\
\text { check-up }\end{array}$ & $\begin{array}{l}\text { CxR at medical } \\
\text { check-up }\end{array}$ & $\begin{array}{l}\text { CxR at medical } \\
\text { check-up }\end{array}$ \\
\hline Symptoms & none & none & none & none \\
\hline Chest CT Features & $\begin{array}{l}\text { well-circumscribed } \\
\text { solid mass with } \\
\text { air-bronchogram }\end{array}$ & $\begin{array}{l}\text { solid mass with } \\
\text { peripheral GGO }\end{array}$ & $\begin{array}{l}\text { well-defined solid } \\
\text { nodule }\end{array}$ & $\begin{array}{l}\text { consolidation with } \\
\text { air-bronchograms and } \\
\text { multiple lung nodules }\end{array}$ \\
\hline Serum LDH & high & normal & normal & normal \\
\hline $\begin{array}{l}\text { Preoperative } \\
\text { Diagnosis }\end{array}$ & $\begin{array}{l}\text { lung cancer or } \\
\text { malignant lymphoma } \\
\text { suspected }\end{array}$ & $\begin{array}{l}\text { pulmonary MALT } \\
\text { suspected }\end{array}$ & $\begin{array}{l}\text { lung cancer } \\
\text { suspected }\end{array}$ & $\begin{array}{l}\text { pulmonary MALT } \\
\text { and/or combined } \\
\text { lung cancer } \\
\text { suspected }\end{array}$ \\
\hline Surgery & left lower lobectomy & $\begin{array}{l}\text { left lower lobe wedge } \\
\text { resection }\end{array}$ & left lower lobectomy & $\begin{array}{c}\text { right upper lobectomy } \\
\text { and lower lobe wedge } \\
\text { resection }\end{array}$ \\
\hline $\begin{array}{l}\text { Ann Arbor' Stage } \\
\text { after Definitive } \\
\text { Diagnosis }\end{array}$ & III & I & I & I \\
\hline Chemotherapy & R-CHOP & $\mathrm{CP}$ & $\mathrm{RB}$ & Rituximab \\
\hline $\begin{array}{l}\text { Time between } \\
\text { Surgery and } \\
\text { Chemotherapy }\end{array}$ & 10 years & 2 months & 6 months & 1 year and 6 months \\
\hline Prognosis & $\begin{array}{c}\text { died of pancreatic } \\
\text { cancer } 26 \text { years after } \\
\text { surgery }\end{array}$ & $\begin{array}{l}\text { alive for } 11 \text { years } \\
\text { after surgery }\end{array}$ & $\begin{array}{c}\text { alive } 2.5 \text { years after } \\
\text { surgery }\end{array}$ & $\begin{array}{l}\text { alive } 1 \text { year and } 8 \\
\text { months after surgery }\end{array}$ \\
\hline
\end{tabular}

GGO: Ground Glass Opacity

CxR: Chest Roentgenography

CT: Computed Tomography

R-CHOP: Rituximab + Cyclophosphamide + Doxorubicine + Vincristine + Prednisone

CP: Cyclophosphamide + Prednisone

RB: Rituximab + Bendamustine

分類され，そのうち $90 \%$ 以上が肺 MALTリンパ腫であ

り, 全肺悪性腫瘍の約 $0.5 \%$ とされている ${ }^{1,2)}$. 肺 MALT

リンパ腫は indorent tumor と表現される緩徐進行型の

MALT リンパ腫に属し, 他の MALT リンパ腫と同様に

予後はよいとされている ${ }^{3)}$. 発見される契機は症例 2,3 ,

4 のように偶然, 胸部 X 線の異常影として発見されるこ

とが多く, リンパ腫の $\mathrm{B}$ 症状(発熱, 寝汗, 体重減少)で 発見されるものは少ない4).

肺 MALT リンパ腫のCT 所見では, 腫瘤から連続す る小葉間隔壁の肥厚や腫瘤周囲に細かい多発粒状影のよ うな比較的特徵的な陰影のほか, 濃度が濃い浸潤影, 腫 瘤影, 結節影, 微細粒状影, 浸潤影, GGO など多彩な像 を示すばかりではなく，またこれらの像が混在すること
も多く ${ }^{5)}$ ，高分化型肺腺癌との鑑別は容易ではない。肺 MALT リンパ腫は気管支鏡による細胞診の確定診断に 至らない場合が多いとされているが(6), 病変が気管支の外 側に発生するため病変部位に到達することが困難なため かもしれない．外科治療の対象とはならない胸水例や両 側あるいは複数葉の多発病変の症例では穿刺による胸膜 播種のリスクより診断確定による治療方針決定のメリッ トが大きいので CT ガイド下生検も行われている. 我々 の 4 例中，気管支鏡検査がなされた 3 例のうち 1 例では 肺 MALT リンパ腫が疑われたものの 2 例は細胞診除性 であり， 3 例とも診断確定には至らなかった (Table 1).

肺 MALT リンパ腫の病理組織学的な特徵は, HE 染色 では肧中心に類似する細胞 (centrocyte-like cells) が増殖 
していること, リンパ滤胞には胚中心が存在すること, 小型のリンパ腫細胞が粘膜上皮に存在し Lymphoepithelial lesion(LEL)を形成することである ${ }^{6}$. これに加えて, 免疫染色では CD20 陽性, 染色体検査で $\mathrm{t}(11: 18)$ の転 座などが認められる.

ヘリコバクター・ピロリ感染が主たる要因の胃 MALTでは, 菌陽性であればまず除菌が試され, 陰性で あれば放射線治療や化学療法を選択するガイドラインが ある7). 一方, 胃以外の MALT リンパ腫では病変が限局 した病期 I ではまず外科治療を行い, 切除断端侩性であ れば経過観察とし, 切除断端に腫瘍遺残があれば放射線 治療を追加することが勧められ, 症例の全身状態によっ ては経過観察も選択肢として提案されている7.8). 肺 MALT リンパ腫には放射線が奏功し, 外科治療, 放射線 治療いずれにても 5 年生存率は $90 \%$ 以上であるという 報告9)もあるので, 気管支鏡検査などにより病理診断が確 定できて病変が限局していれば放射線治療による治療も 選択肢となる. また, 疾患が $\mathrm{B}$ 細胞リンパ腫であること から 90 年代末に登場したCD20 モノクロナール抗体で あるリッキシマブを主体とした化学療法も選択肢になり うる. 胃 MALT リンパ腫以外の MALT に対する外科治 療は, 病変が単独であれば上位の治療選択肢であるが7 症 例 3, 4 のように比較的早期に, あるいは症例 1 のように 長い年月後に異時性に肺以外の部位の新規の病変が出現 した折に化学療法でこれらの病変がコントロールできた ことや, この疾患が当初の MALT の播種によって発症 するあるいは別の臓器における慢性炎症により発症する 機序を考慮すると, 長い病悩期間を想定し, 肺切除量は 個々の症例にとって必要最小限にする慎重な判断が求め られる.リツキシマブが登場する以前に同時性に小腸と 肺に MALT が出現した症例 1 では局所コントロールが 完遂できる左下葉切除を選択したが，現時点であればリ ツキシマブなどの化学療法が選択肢となると考えられ $ろ^{7}$.

今回, 経験した 4 症例では, 血液内科医が個々の患者 さんの臨床経過, 腫瘍量, 再発部位あるいは再発防止の 希望などの条件に基づき, 個々に術後化学療法に対する 判断を行った. 肺 MALT リンパ腫は緩徐進行であるの で無治療経過観察の選択もありうるが，まれにびまん性 大細胞型リンパ腫を発症することがあり ${ }^{2.3)}$, その場合に は予後不良となることが報告されているので慎重な観察 と病変に応じた治療が必要となる。
MALT はいろいろな臟器における感染症などによる 慢性炎症刺激や自己免疫により発症しうるので, 複数の 臟器に同時に，あるいは異時的に出現したときに，それ ぞれの臓器の MALT が同一クローンなのか別のクロー ンなのかが問題となる ${ }^{10)}$. 近年, これを調べる方法とし て, 免疫グロブリン重鎖遺伝子の発現を PCR 法で比較し た報告が散見される。 Oh ら ${ }^{11}$ は，ピロリ菌が関与する胃 MALT から 2 年後に結核治療後にMALT が出現した 例で後者がより多クローン性を有していたことから，そ れぞれが別個に出現したことを報告している. Konoplev $ら^{12}$ は 4 例中 1 例のみがモノクローン, 3 例は多クローン であり，それぞれの臓器での慢性刺激が B 細胞の増殖に つながることを示唆した.このような複数臓器の MALT の起源の探索による，治療方針の決定や予後予測につい ての臨床的な意義はいまだ明らかにされてはいないが, Wang ${ }^{13)}$ はこのような解析がなされた最近の 7 報告 21 例を, 複数臟器の MALT が同一クローンの症例のほう が別のクローンの症例より予後が不良な傾向があること を示唆した ${ }^{13}$. 今回の症例であれば, 例えば症例 1 は同時 に小腸と肺に腫瘤として発見されたので，このようなこ とが可能となった年代であれば検索できたかもしれな い.しかし, MALT 発見時に $1 / 3$ の例では複数部位に病 変が確認されるものの限局した例と複数臓器出現例との 間に予後に差はないこと和や, MALT のクローン起源に ついての探索の高コストを考慮すると, 現時点では臨床 的には個々の患者の状態に応じて外科治療, 放射線治療, 化学療法を適切に選択すればよいのではないかと考えら れる ${ }^{11,12)}$.

\section{結語}

肺切除により診断が確定し, 術後の経過中の病態に応 じて化学療法を行い, 良好な経過の肺 MALT リンパ腫 4 例を報告した。

\section{利 益相 反}

本論文について申告する利益相反はない.

\section{文献}

1. Freeman C, Berg JW, Cutler SJ. Occurrence and prognosis of extranodal lymphomas. Cancer 1972; 29: 252-60.

2. Ferraro P, Trastek VF, Adlakha H, Deschamps C, Allen MS, Pairolero PC. Primary non-Hodgkin's lymphoma of 
the lung. Ann Throrac Surg 2000; 69: 993-7.

3. Koss MN. Malignant and benign lymphoid lesions of the lung. Ann Diagn Pathol 2004; 8: 167-87.

4. Fraser RS, Colman NC, Muller NL, Pare PD 編. 清水 英治, 藤田次郎監訳. フレイザー 呼吸器病学エッセン ス. 第 1 版. 東京：西村書店；2009.

5. 楠本昌彦. まれな肺腫瘍の画像診断. 肺癌 2015; 55: 103744.

6. 桑原元尚, 光武孝倫, 頴原 隆, 光井 敬, 石橋正敏, 白 日高歩. 18FDG-PETが診断に有用であった多発 bronchus-associated lymphoid tissue リンパ腫の 1 例. 日 胸 2007; 66: 502-8.

7. 一般社団法人 日本血液学会編. 造血器腫瘍診療ガイド ライン 2018 年版. 第 2 版. 東京 : 金原出版 ; 2018 .

8. 臼杵憲祐, 浦部晶夫. 肺リンパ腫の治療. 日胸 2007; 66: 198-209.

9. Cordier JF, Chailleux E, Lauque D, Reynaud-Gaubert M, Dietemann-Molard A, Dalphin JC, et al. Primary pulmonary lymphomas. A clinical study of 70 cases in nonim- munocompromised patients. Chest 1993; 103: 201-8.

10. Thieblemont C, Berger F, Dumontet C, Moullet I, Bouafia F, Felman P, et al. Mucosa-associated lymphoid tissue lymphoma is a disseminated disease in one third of 158 patients analyzed. Blood 2000; 95: 802-6.

11. Oh SY, Kim NY, Oh DH, Bang SM, Choi YJ, Lee JY, et al. Concurrent Gastric and Pulmonary Mucosa-Associated Lymphoid Tissue Lymphomas with Pre-Existing Intrinsic Chronic Inflammation: A Case Report and a Review of the Literature. Gut Liver 2015; 9: 424-9.

12. Konoplev S, Lin P, Qiu X, Medeiros LJ, Yin CC. Clonal relationship of extranodal marginal zone lymphomas of mucosa-associated lymphoid tissue involving different sites. Am J Clin Pathol 2010; 134: 112-8.

13. Wang Y, Dong S, Jiang Z, Li A. A case report of concurrent gastric and pulmonary mucosa-associated lymphoid tissue lymphomas and review of the literature on clonality analysis. Ann Hematol 2013; 92: 1707-9.

\title{
Pulmonary mucosa-associated lymphoid tissue lymphoma: Report of four patients receiving lung resection followed by chemotherapy
}

\author{
Hayato Nanami* ${ }^{* 1}$, Ryo Miyoshi*1, Kyoko Hijiya*1 \\ Toshiaki Moriki*2, Akinori Maeda ${ }^{* 3}$, Koji Chihara*1 \\ ${ }^{* 1}$ Department of Thoracic Surgery, ${ }^{* 2}$ Department of Pathology, ${ }^{* 3}$ Department of Hematology, \\ Shizuoka City Shizuoka Hospital, Shizuoka, Japan
}

We report four patients ( 3 females and 1 male, mean age of 62 years) with pulmonary mucosa-associated lymphoid tissue (MALT) lymphoma confirmed by lung resection, and followed by chemotherapy. They had various CT features such as a well-circumscribed mass, nodule, or consolidation mimicking lung cancer. Bronchoscopy was performed for three of the four, but failed to result in a definitive diagnosis in any case. Lung resection was performed in all patients for the purposes of diagnosis and treatment, and pathological examination led to a definitive diagnosis of pulmonary MALT lymphoma. Adjuvant chemotherapy was performed in two patients, while it was administered as treatment for newly appearing lesions in other organs during the long-term follow-up period. One of the four patients died of another cancer 25 years after surgery. Three patients survived for 11 years, 2 and a half years, and 1 year and 8 months after surgery, respectively. We believe that pulmonary resection combined with close follow-up and treatment by a hematologist is effective to treat patients with pulmonary MALT lymphoma. 